\title{
SKUTKI ZMIAN REGULACJI PRAWNYCH W ZAKRESIE EMERYTUR KAPITAŁOWYCH DLA ROZWOJU RYNKU FINANSOWEGO W POLSCE
}

\section{WSTĘP}

Pozycja funduszy emerytalnych i ich wpływ jako katalizatora rozwoju rynku kapitałowego jest $\mathrm{w}$ dużym stopniu zdeterminowana rozmiarami zakumulowanego portfela aktywów. Dane statystyczne dowodzą, że wartość aktywów OFE przewyższała zarówno wartość aktywów funduszy inwestycyjnych w latach 2002-2009, jak i aktywów zakładów ubezpieczeń w latach 2006-2009¹. Wartość aktywów OFE ulegała dynamicznemu wzrostowi, zwłaszcza w początkowej fazie wdrożenia reformy emerytalnej w latach 1999-2003 (przeciętnie 40\% rocznie), kiedy największy wpływ na wartość aktywów miał dopływ składek, będący pochodną liczby aktywnych członków funduszy. Natomiast, w kolejnych latach funkcjonowania, coraz większą rolę w kształtowaniu wartości aktywów OFE zaczęła odgrywać efektywność realizowanej działalności inwestycyjnej, a strumień przepływów pieniężnych $\mathrm{z}$ tytułu składek był coraz mniejszy w relacji do zarządzanych aktywów. Na koniec 2010 roku OFE dysponowały już aktywami netto o wartości ponad 221,3 mld zł, co oznacza wzrost o $60 \%$ w relacji do roku 2008.

Polityka inwestycyjna otwartych funduszy emerytalnych jest uwarunkowana $z$ jednej strony ograniczeniami prawnymi w zakresie kształtowania struktury portfela inwestycji, $\mathrm{z}$ drugiej zaś sytuacją makroekonomiczną i koniunkturą

\footnotetext{
${ }^{1}$ Rozwój systemu finansowego w Polsce w 2009 r., NBP, Warszawa 2010.
} 
rynków finansowych ${ }^{2}$. W celu ograniczenia stopnia ekspozycji na ryzyko, działalność inwestycyjna funduszy emerytalnych jest poddana ograniczeniom ze strony ustawodawcy ${ }^{3}$. W portfelu inwestycji otwartych funduszy emerytalnych dominującym składnikiem są instrumenty dłużne, przede wszystkim obligacje i bony skarbowe (wykres 1). Drugą, co do wielkości, kategorią portfela inwestycji OFE były akcje spółek, które stanowiły od 22\% w roku 2008 (udział minimalny) do 36,4\% w roku 2010 portfela inwestycji (udział maksymalny). Portfel ten $\mathrm{z}$ reguły uzupełniany był depozytami bankowymi, które wykorzystywane były jako instrument zarządzania płynnością przy rebalancingu portfela. Wyraźnie widoczny jest wzrost udziału akcji w portfelach OFE w latach 2006-2007 oraz 2009-2010, co związane było z dobrą koniunkturą giełdową. Natomiast zwiększaniu zaangażowania funduszy w instrumenty dłużne sprzyjała niekorzystna sytuacja na GPW oraz sytuacja na rynku obligacji w 2. połowie 2008 roku (wzrost wyceny obligacji o stałym oprocentowaniu - w okresie od czerwca do grudnia 2008 roku indeks obligacji polskich wzrósł o prawie $9 \%)^{4}$. Struktura portfela inwestycji OFE była zdeterminowana sytuacją na polskim rynku finansowym - rynek płytki, o dość niskiej płynności, duża podaż i wysoka rentowność skarbowych papierów dłużnych oraz niekorzystna koniunktura na rynku giełdowym w latach 2001-2002 i 2008, a także brakiem ograniczeń w zakresie inwestowania w skarbowe papiery wartościowe oraz limitem 5\% na inwestycje na zagranicznych rynkach finansowych.

Doświadczenia wielu krajów pokazują, że aktywność inwestycyjna funduszy emerytalnych należy do tzw. akceleratorów rozwoju rynku finansowego zarówno $\mathrm{w}$ aspekcie organizacyjno-prawnym, jak również sama akumulacja długoterminowego kapitału w tych instytucjach przyczynia się do generowania popytu na profesjonalizację i specjalizację procesu inwestycyjnego oraz stymuluje innowacje finansowe ${ }^{5}$. Zaangażowanie funduszy emerytalnych na rynku

2 T. T. Czerwińska, Polityka inwestycyjna instytucji ubezpieczeniowych - istota, uwarunkowania, instrumenty, Wyd. Uniwersytetu Gdańskiego, Gdańsk 2009.

${ }^{3}$ Ustawa z dnia 28 lipca 1997 r. o organizacji i funkcjonowaniu funduszy emerytalnych (Dz. U. z 20 XI 1997 r. z późn. zm.) Rozporządzenie Rady Ministrów z dnia 3 lutego 2004 r. w sprawie określenia maksymalnej części aktywów OFE, jaka może zostać ulokowana w poszczególnych kategoriach lokat, oraz dodatkowych ograniczeń w zakresie prowadzenia dziatalności lokacyjnej przez fundusze emerytalne, (Dz.U. Nr 32, poz. 276, z późn. zm.); Rozporządzenie Ministra Finansów z 18 lutego 2000 r. w sprawie ogólnego zezwolenia na lokowanie aktywów funduszy emerytalnych poza granicami kraju (Dz.U.00.15.182.).

${ }^{4}$ Informacja o dziatalności inwestycyjnej funduszy emerytalnych w okresie 29.09.2006 - 30.09.2009, KNF, Warszawa 2009.

${ }^{5}$ K. Kołodziejczyk, Systemy emerytalne w Ameryce Eacinskiej: od repartycji do kapitalizacji, Wydawnictwo WSB w Poznaniu, Poznań 2004, s. 102-103 
giełdowym może pełnić funkcje stabilizującą koniunkturę na rynku, co jest niezwykle istotne dla stabilności systemu finansowego zwłaszcza w czasach globalnego kryzysu gospodarczego.

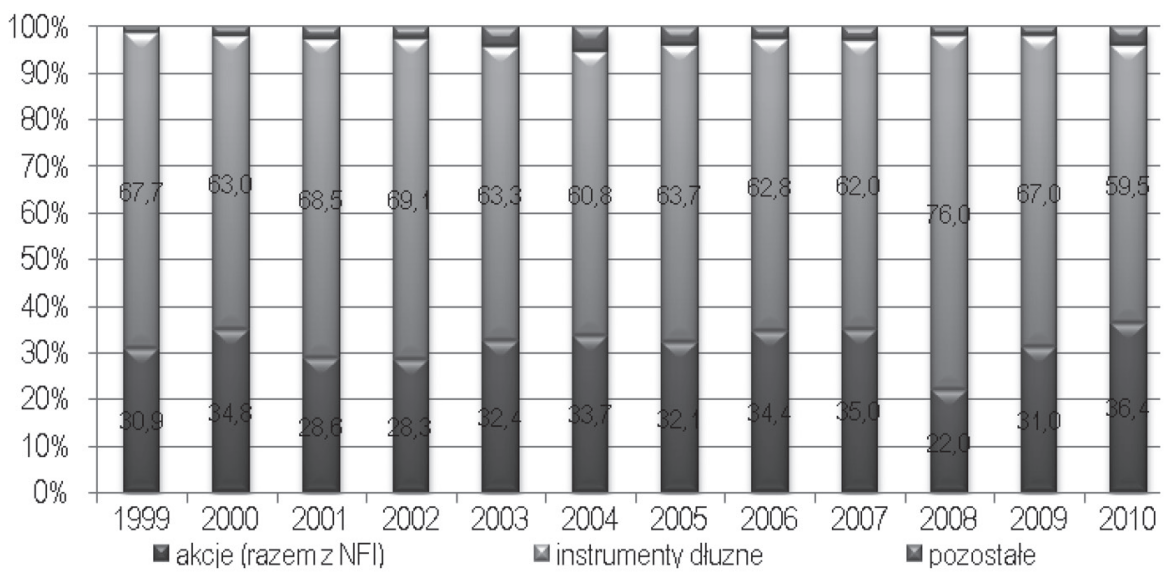

Wykres 1. Struktura zagregowana portfela OFE w latach 1999-2010 (w \%) Źródło: opracowanie własne na podstawie danych KNF.

Celem opracowania jest identyfikacja i analiza przewidywanych skutków zmian regulacji prawnych w zakresie emerytur kapitałowych dla rozwoju rynku finansowego w Polsce.

\section{ZASADNICZE ELEMENTY PLANOWANYCH ZMIAN W SYSTEMIE EMERYTALNYM}

Zasadniczym celem planowanych zmian jest ograniczenie tempa przyrostu długu publicznego przez redukcję kosztów funkcjonowania kapitałowego filara systemu ubezpieczeń społecznych ${ }^{6}$. Do najbardziej istotnych zmian proponowanych $\mathrm{w}$ projekcie Ustawy o zmianie niektórych ustaw zwiqzanych z funkcjonowaniem systemu ubezpieczeń społecznych, mających wpływ na rozwój rynku finansowego w Polsce należy zaliczyć:

${ }^{6}$ Według szacunków Ministerstwa Finansów w 2010 roku wysokość refundacji FUS składki przekazywanej do OFE wyniosła 22,5 mld zł. (co stanowi 1,6\% prognozowanego PKB), natomiast w latach 1999-2010 bezpośredni koszt refundacji z budżetu państwa ubytku składki emerytalnej w FUS, w wyniku jej przekazywania do OFE, wyniósł ok. 162 mld zł., co stanowi ok. 11,5\% prognozowanego na 2010 r. PKB. (M. Boni, Uzasadnienie do Ustawy o zmianie niektórych ustaw związanych z funkcjonowaniem systemu ubezpieczeń spotecznych, KPRM 2011, www.kprm.gov.pl). 
- obniżenie poziomu składki przekazywanej do OFE;

- zmiany limitów działalności inwestycyjnej OFE;

- wprowadzenie zachęt podatkowych do dobrowolnego gromadzenia dodatkowych oszczędności emerytalnych.

Planowane zmiany przewidują obniżenie składki przekazywanej do OFE $\mathrm{z}$ obecnych $7,3 \%$ podstawy wymiaru na ubezpieczenie emerytalne do 2,3\% (od maja 2011 do końca 2012 roku). Pozostała część składki, czyli 5\% podstawy wymiaru na ubezpieczenie emerytalne, będzie zapisywana na indywidualnym subkoncie emerytalnym w ZUS. W kolejnych latach część składki emerytalnej przekazywanej do OFE ma stopniowo wzrastać kosztem składki przekazywanej do ZUS, odpowiednio: do 2,8\% podstawy wymiaru na ubezpieczenie emerytalne w 2013 roku, 3,1\% w 2014 roku, 3,3\% w latach 2015-2016 oraz do 3,5\% w $2017 \mathrm{roku}^{7}$. Środki gromadzone na subkoncie w ZUS, w ramach II filara, będą waloryzowane według średniego nominalnego wzrostu PKB $\mathrm{z}$ ostatnich pięciu lat (zastrzegając nieujemną stopę waloryzacji).

W proponowanych założeniach jest również propozycja odnośnie zmian w obowiązujących regulacjach prawnych dotyczących działalności inwestycyjnej funduszy emerytalnych. Najistotniejsza zmiana dotyczy zwiększenia limitu zaangażowania OFE w akcje spółek notowanych na regulowanym rynku giełdowym, a także w notowane na regulowanym rynku giełdowym prawa poboru, PDA, obligacje zamienne na akcje tych spółek oraz akcje NFI docelowo do $90 \%$ wartości aktywów funduszu ${ }^{8}$. Zmiana ta ma mieć charakter ewolucyjny, bowiem zakłada się, że limit zaangażowania w wymienione instrumenty finansowe będzie wzrastał stopniowo, w relacji do obecnego limitu 40\%, a mianowicie w latach 2011-2014 rocznie o 2,5\%, natomiast w latach 2015-2020 o 2\% rocznie. W 2020 roku limit ten określi maksymalne zaangażowanie OFE $\mathrm{w}$ akcje notowane na rynku regulowanym na poziomie 62\% aktywów.

Proponowane jest również wprowadzenie zachęt podatkowych do dobrowolnego gromadzenia dodatkowych oszczędności emerytalnych. Nie rezygnując $z$ dotychczasowych form dobrowolnego gromadzenia oszczędności emerytalnych, wprowadza się możliwość założenia jednego dodatkowego Indywidualnego Konta Zabezpieczenia Emerytalnego (IKZE). Wpłaty na IKZE ustalono w wysokości $4 \%$ podstawy wymiaru składki na ubezpieczenie emerytalne (lub do wysokości 4\% równowartości 12-krotności minimalnego wyna-

7 Art. 19, Ustawa o zmianie niektórych ustaw związanych $\mathrm{z}$ funkcjonowaniem systemu ubezpieczeń społecznych, projekt $\mathrm{z}$ dnia 3 marca 2011 r., www.kprm.gov.pl.

8 Ustawa o zmianie niektórych ustaw związanych z funkcjonowaniem systemu ubezpieczeń spotecznych, art. 4, pkt. 34, projekt z dnia 3 marca 2011 r., www.kprm.gov.pl. 
grodzenia za pracę $\mathrm{w}$ poprzednim roku kalendarzowym) ${ }^{9}$. Wpłaty te będą odliczane od podstawy opodatkowania podatkiem dochodowym od osób fizycznych. Zachętą do dodatkowego oszczędzania jest także zwolnienie z podatku od zysków kapitałowych. Ponadto, w okresie od 1 stycznia 2012 do 31 grudnia 2012 wpłaty na IKZE można dokonać przenosząc środki zgromadzone na IKE. Środki te wówczas będą również podlegać odliczeniu od dochodu przy naliczaniu podatku dochodowego od osób fizycznych ${ }^{10}$. Przyjęto, że opodatkowaniu będzie podlegał zwrot całkowity z IKZE.

Projekt przewiduje, że IKZE może być prowadzone poprzez zawarcie umowy z: funduszem inwestycyjnym, podmiotem prowadzącym działalność maklerską, zakładem ubezpieczeń na życie lub też z bankiem o prowadzenie rachunku bankowego. Jest to rozwiązanie wzorowane na regulacjach prawnych dotyczących IKE ${ }^{11}$. Natomiast, nowym rozwiązaniem jest umożliwienie gromadzenia środków na IKZE i IKE poprzez zawarcie umowy z dobrowolnym funduszem emerytalnym prowadzonym przez powszechne towarzystwo emerytalne (PTE). Mając na uwadze długoterminowy cel gromadzenia kapitału na IKZE, przewiduje się, że zgromadzone na IKZE środki będą wypłacane wyłącznie (od wieku 65 lat dla mężczyzn i 60 lat dla kobiet i po min. pięciu latach przekazywania składek) $\mathrm{w}$ formie ${ }^{12}$ :

- emerytury dożywotniej;

- rat w okresie minimum 10 lat, lub

- jednorazowej wypłaty (dopisanie całej kwoty do podstawy wymiaru podatku dochodowego od osób fizycznych).

Proponowane przez rząd zmiany regulacji prawnych w systemie emerytur kapitałowych, mające na celu przede wszystkim wdrożenie rozwiązań optymalnych z punktu widzenia systemu finansów publicznych, będzie miało niewątpliwie daleko idące konsekwencje dla rozwoju i funkcjonowania rynku finansowego w Polsce. Nie wdając się - ze względu na główny nurt prowadzonych rozważań - w szczegółową analizę złożonej i wielowątkowej problematyki dotyczącej zarówno rozwiązań prawnych, jak i idei solidarności społecznej w systemie emerytalnym, warto wskazać konsekwencje zmian tychże regulacji dla rynku kapitałowego, zwłaszcza dla rynku giełdowego akcji, rynku instrumentów dłużnych oraz środowiska instytucji finansowych.

9 Ustawa o zmianie niektórych ustaw zwiqzanych z funkcjonowaniem systemu ubezpieczeń spotecznych, art. 11, pkt. 13, projekt z dnia 3 marca 2011 r., www.kprm.gov.pl.

${ }_{10}$ Nadwyżka tej wpłaty ponad limit wpłat przypadający w danym roku podatkowym będzie podlegała odliczeniu w kolejnych latach. W okresie odliczeń od dochodu środków przeniesionych z IKE na IKZE, oszczędzającemu nie przysługuje prawo do wpłat na IKZE.

11 Ustawa z dnia 20 kwietnia 2004 r. o indywidualnych kontach emerytalnych.

12 Ustawa o zmianie niektórych ustaw zwiqzanych z funkcjonowaniem systemu ubezpieczeń spotecznych, art. 11, projekt z dnia 3 marca 2011 r., www.kprm.gov.pl. 


\section{OCENA PRZEWIDYWANYCH SKUTKÓW ZMIAN W SYSTEMIE EMERYTALNYM DLA RYNKU FINANSOWEGO}

Istotne skutki dla rozwoju rynku kapitałowego będzie miała zmiana dotycząca zmniejszenia składki przekazywanej do OFE z 7,3\% do 2,3\% podstawy wymiaru na ubezpieczenie emerytalne od maja 2011 roku, co będzie skutkowało nie tylko zmniejszeniem dynamiki przyrostu wartości aktywów OFE, ale przede wszystkim znaczną redukcją strumienia kapitału kierowanego na rynek kapitałowy. Należy podkreślić, że zmniejszenie składki przekazywanej do OFE zgodnie z planowanym harmonogramem, oznacza redukcje dopływu kapitału do OFE o 68,5\% już w latach 2011-2012. W celu ekstrapolacji wartości aktywów netto funduszy emerytalnych opracowano model prognostyczny na podstawie danych Komisji Nadzoru Finansowego oraz GUS z lat 2002-2010 oraz przyjęto następujące założenia:

- Liczba aktywnych członków OFE na koniec 2010 roku - 14,93 mln osób. Wartość składek przekazanych przez ZUS w 2010 roku do OFE wyniosła 22,99 mld zł. Do końca 2008 roku nie były jeszcze wypłacane świadczenia ze środków zgromadzonych w funduszach emerytalnych, co w połączeniu ze strukturą demograficzną społeczeństwa przyczyniało się do ciągłego wzrostu liczby członków OFE. Biorąc pod uwagę fakt, że w latach 2000-2010 tempo przyrostu nowych członków funduszy ustabilizowało się na poziomie ok. 500 tys. osób rocznie, można przyjąć, że w najbliższych latach według ostrożnych szacunków liczba członków OFE będzie wzrastała średnio w latach 2011-2015 o ok. 500 tys. rocznie. Następnie w latach 2016-2019, będzie następował spadek dynamiki wzrostu liczby członków o 400 tys. rocznie. Następnie, od 2020 roku wraz ze zmniejszającą się liczebnością osób najmłodszych przystępujących do OFE oraz stopniowym wzrostem liczebności osób uzyskujących uprawnienia emerytalne, liczebność członków OFE zmniejszy się, zatem zakłada się szacunkowy wzrost liczby członków o 300 tys. rocznie.

- Wskaźnik zatrudnienia w grupie wiekowej 18-59/64 lata będzie utrzymywał się na poziomie zbliżonym do obecnie obserwowanego na polskim rynku pracy, czyli $65 \%$.

- Coroczny wskaźnik wzrostu składki przekazywanej do funduszy, wynikający ze średniego rocznego tempa wzrostu wynagrodzeń, przyjęto na poziomie $4 \%$.

- Wysokość opłaty dystrybucyjnej przyjęto na poziomie 3,5\% składki w całym okresie prognozy. 
- Biorąc pod uwagę znaczne zróżnicowanie wysokości opłat za zarządzanie pobieranych przez poszczególne OFE, w szacunkach pominięto te opłaty.

- Średnioroczna stopa zwrotu OFE na poziomie 5\% rocznie.

Biorąc pod uwagę planowane zmiany w zakresie zmniejszenia składki przekazywanej do OFE rozpatrzono dwa scenariusze dopływu składek:

- scenariusz I - bazowy: utrzymanie dotychczasowego poziomu składki $7,3 \%$ podstawy wymiaru na ubezpieczenie emerytalne;

- scenariusz II: obniżenie poziomu składki do 2,3\% podstawy wymiaru na ubezpieczenie emerytalne od maja 2011 do końca 2012 roku, a następnie stopniowy wzrost składki emerytalnej przekazywanej do OFE odpowiednio: do $2,8 \%$ podstawy wymiaru na ubezpieczenie emerytalne w 2013 roku, 3,1\% w 2014 roku, 3,3\% w latach 2015-2016 oraz do 3,5\% w $2017 \mathrm{roku}^{13}$.

W przypadku scenariusza bazowego, zakładającego składkę na poziomie $7,3 \%$ podstawy wymiaru na ubezpieczenie emerytalne, wartość aktywów OFE w 2020 roku przekroczyłaby 791,4 mld zł., co stanowiłoby wzrost o $257 \%$ w relacji do 2010 roku. Natomiast, w przypadku obniżenia poziomu składki do proponowanych $2,3 \%$ podstawy wymiaru na ubezpieczenie emerytalne (i następnie zgodnie $\mathrm{z}$ harmonogramem), wartość aktywów OFE wzrośnie w perspektywie 2020 roku do $554 \mathrm{mld}$ zt, czyli wzrost o 150,4\% w relacji do 2010 roku (wykres 2). Wprowadzenie planowanych zmian w regulacjach prawnych będzie miało zasadniczy wpływ zarówno na pozycję samych funduszy emerytalnych na rynku finansowym, która jest warunkowana wartością portfela aktywów, jak i na funkcjonowanie i rozwój tego rynku, bowiem aktywność inwestycyjna OFE kształtuje też w znacznej mierze koniunkturę na rynku finansowym.

Zmniejszenie składki przekazywanej do OFE oznacza zmniejszenie dopływu środków przede wszystkim na rynek instrumentów udziałowych, zwłaszcza giełdowy. Wskazuje na to dysonans między założeniem o stopniowym wzroście limitu na instrumenty udziałowe (przede wszystkim akcje spółek notowane na rynku giełdowym) poczynając od 2011 roku zaledwie o 2,5\% rocznie (a docelowo do 62\% portfela aktywów OFE w 2020 roku) - z jednej strony, przy jednoczesnym radykalnym ograniczeniu dopływu składek do OFE już od maja 2011 roku o wspomniane blisko 70\%.

Nietrudno jednak przewidzieć, że niezbędna nowelizacja rozporządzenia nie pojawi się równocześnie $\mathrm{z}$ ustawą wprowadzającą obniżenie składki przekazywanej do OFE. Zatem, nieadekwatne do tempa redukcji składki, powolne

13 Ustawa o zmianie niektórych ustaw zwiazanych z funkcjonowaniem systemu ubezpieczen spotecznych, art. 19, projekt z dnia 3 marca 2011 r., www.kprm.gov.pl. 
tempo wzrostu limitu inwestycji w akcje może przyczynić się, wbrew zapowiedziom, do zjawiska wypierania instrumentów udziałowych z portfeli OFE i znacznie ograniczy dopływ kapitału na GPW. W perspektywie, zmniejszenie strumienia środków przeznaczanego przez OFE na inwestycje w akcje na rynku publicznym, może spowodować trudności z pozyskiwaniem kapitału przez przedsiębiorstwa na GPW, zmniejszenie liczby IPO oraz spadek tempa wzrostu kapitalizacji.

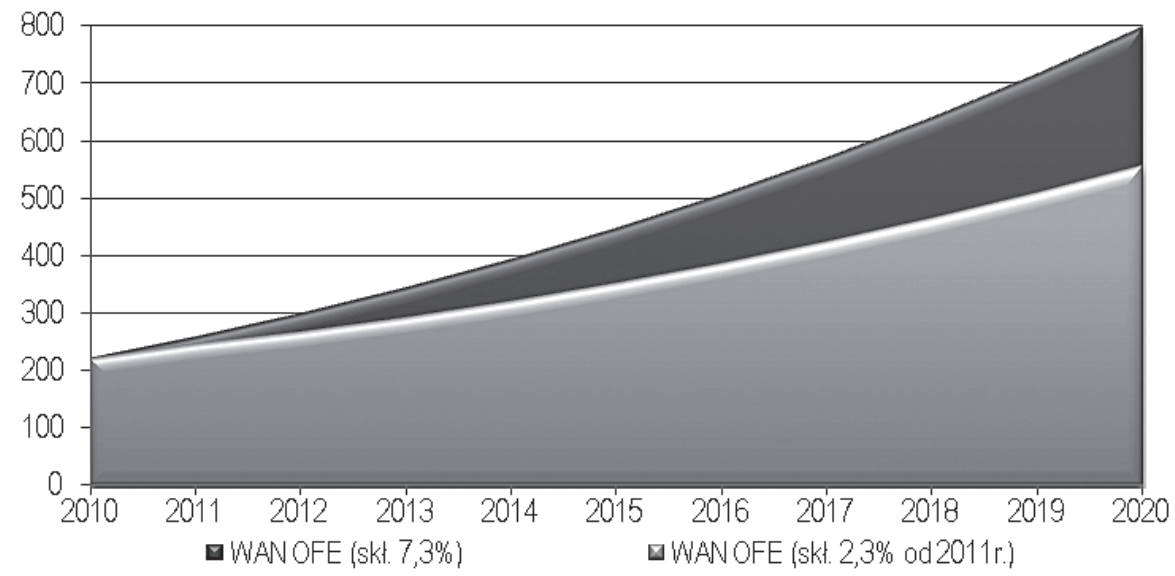

Wykres 2. Prognoza wartości aktywów netto OFE w latach 2011-2020 (w mld zł.) Źródło: obliczenia własne.

Wartość zarządzanego przez fundusze emerytalne portfela akcji sprawia, że ich decyzje wywierają obecnie znaczny wpływ na funkcjonowanie polskiego rynku giełdowego. Dopływ kapitału o charakterze długoterminowym na GPW - z jednej strony - może przyczynić się do zapewnienia większej stabilizacji krajowego rynku giełdowego, natomiast, z drugiej strony - znaczny udział OFE we free float rodzi niebezpieczeństwo zmniejszenia płynności rynku giełdowego oraz powstawania tzw. „baniek spekulacyjnych”. W sytuacji znaczącego pogorszenia się koniunktury na rynku giełdowym w konsekwencji kryzysu finansowego w 2008 roku, OFE odegrały na GPW funkcję stabilizująca, podtrzymując indeksy przed dalszymi spadkami (stopa zwrotu $\mathrm{z}$ indeksu WIG wyniosła w 2008 roku -51,07). Fundusze emerytalne dokonały w 2008 roku inwestycji na rynku giełdowym łącznie za kwotę 9,2 mld zł, a saldo kupna/sprzedaży akcji w tym roku kilkakrotnie przekroczyło wartość zakupów netto w 2007 roku, kiedy kształtowało się na poziomie około 2 mld zł (NBP 2009). W konsekwencji udział OFE we free float giełdy oraz w kapi- 
talizacji istotnie wzrósł. Zatem, można się spodziewać, że spadek roli OFE jako jednego z najważniejszych długoterminowych inwestorów giełdowych, będzie wiązać się ze zmniejszeniem stabilności tego rynku.

Prognozując udział portfela akcji znajdujących się w posiadaniu OFE w kapitalizacji GPW na podstawie analizy szeregów czasowych, można przyjąć:

- średnioroczne tempo wzrostu kapitalizacji GPW 20\%, przy założeniu kontynuacji przez Skarb Państwa polityki prywatyzacji przedsiębiorstw państwowych o dużej wartości rynkowej;

- wartość obrotów na rynku akcji będzie wzrastać w tempie adekwatnym do kapitalizacji 20\% rocznie;

- OFE będą inwestowały na rynku giełdowym akcji wykorzystując limit zaangażowania w 78\% (co jest adekwatne do historycznych wyników w zakresie wykorzystania limitu przez OFE na akcje w latach 1999 - styczeń 2011) ${ }^{14}$ przy składce na poziomie $7,3 \%$ podstawy wymiaru na ubezpieczenie emerytalne i niezmienionych limitach inwestycyjnych - w bazowym wariancie prognozy;

- w II wariancie prognozy zakłada się, zgodnie z planowanymi zmianami zmniejszenie składki do 2,3\% podstawy wymiaru na ubezpieczenie emerytalne od maja 2011 roku (i dalej zgodnie z planowanym harmonogramem) przy równoczesnym stopniowym zwiększaniu limitów zaangażowania $\mathrm{w}$ akcje, co pozwoli funduszom na lokowanie $\mathrm{w}$ akcje do 62\% wartości aktywów w 2020 roku. Zakłada się, że OFE utrzymają dotychczasowe średnie wykorzystanie obowiązującego limitu zaangażowania w akcje na dany rok na poziomie przeciętnie 78\%. Zakłada się również, że planowana zmiana limitów wejdzie w życie od 2012 roku, zatem fundusze będą inwestować w akcje odpowiednio: 31,2\% w 2011 roku, 33,2\% w 2012 roku, 35,1\% w 2013 roku, 37,1\% w 2014 roku, 39\% w 2015 roku, 40,6\% w 2016 roku, 42,1\% w 2017 roku, 43,7\% w 2018 roku, 45,2\% w 2019 roku oraz 46,8\% w 2020 roku wartości aktywów;

- struktura popytu kierowanego przez OFE na rynek giełdowy będzie kształtowała się w proporcji: 20\% środków na zakup akcji na rynku pierwotnym (IPO) oraz 80\% na nabywanie akcji w obrocie wtórnym (co jest adekwatne do wyników historycznych).

Biorąc pod uwagę wariant bazowy prognozy, zakładający składkę na poziomie $7,3 \%$ podstawy wymiaru na ubezpieczenie emerytalne, udział portfela akcji funduszy emerytalnych w kapitalizacji GPW mógłby ukształtować się na poziomie od 8,43\% w 2011 roku do 5,05\% w 2020 roku przy założeniu,

\footnotetext{
${ }^{14}$ Wyliczenia GPW SA, luty 2011.
} 
że fundusze wykorzystywałyby $40 \%$ - limit zaangażowania w akcje na dotychczasowym przeciętnym poziomie $78 \%$. Należy jednak mieć na uwadze, że udział OFE w wolnym obrocie może być znacznie wyższy (w latach 20052008 kształtował się on na poziomie ok. 20\%, a w 2010 roku ok. $17 \%)^{15}$, co $\mathrm{w}$ większym stopniu odzwierciedla rangę inwestycji funduszy emerytalnych dla rynku giełdowego.

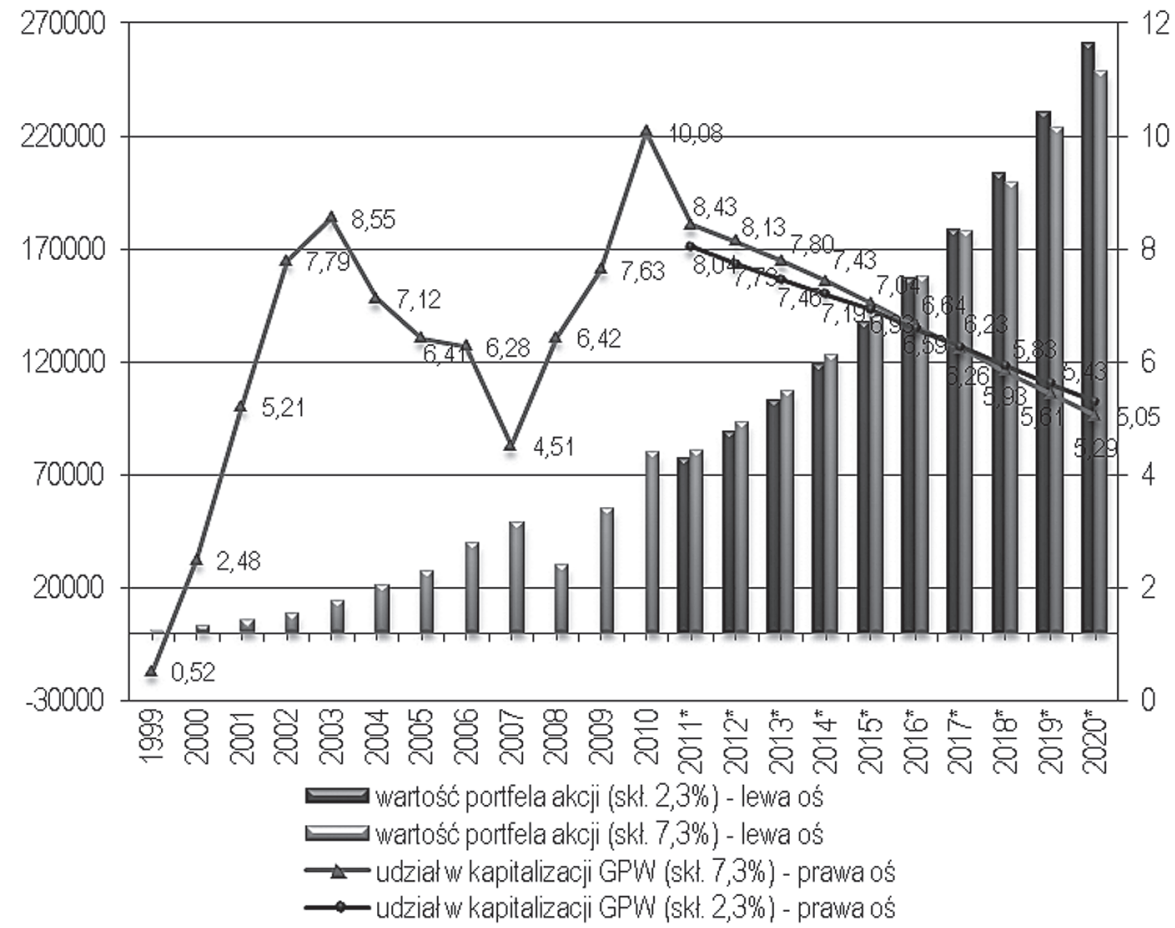

Wykres 3. Wartość i udział zagregowanego portfela akcji OFE w kapitalizacji GPW w Warszawie w latach 1999-2020* (w mln zł, w \%)

* od 2011 r. prognoza scenariuszowa: składka 7,3\% lub 2,3\% podstawy wymiaru na ubezpieczenie emerytalne, wykorzystanie limitu na akcje w 78\%

Źródło: obliczenia własne na podstawie danych KNF i GPW S.A.

Natomiast, w przypadku obniżenia poziomu składki do proponowanego 2,3\% podstawy wymiaru na ubezpieczenie emerytalne od maja 2011 roku (i dalej zgodnie $z$ harmonogramem) oraz zwiększenia limitu na akcje, udział

15 Informacja o dziatalności inwestycyjnej funduszy emerytalnych w okresie 28.09.2007-30.09.2010, KNF, Warszawa 2010. 
OFE w kapitalizacji GPW będzie w latach 2011-2016 mniejszy odpowiednio: 8,04\% i 6,59\%, natomiast następnie w latach 2017-2020 wzrośnie do $5,29 \%$ w 2020 roku (w relacji do poprzedniego wariantu prognozy). W sytuacji znacznej przebudowy portfela, zwłaszcza w przypadku dużych funduszy, udział popytu/podaży OFE w wartości obrotów giełdowych może znacząco wzrosnąć, nawet do 15-20\%. Wówczas, biorąc pod uwagę płytkość naszego rynku, pojawia się istotne niebezpieczeństwo dla płynności rynku giełdowego. Zatem, warunkiem pozytywnego oddziaływania funduszy emerytalnych na stabilizację krajowego rynku giełdowego jest stymulowanie jego płynności, kontynuacja prywatyzacji dużych przedsiębiorstw państwowych oraz pozyskiwanie emitentów zagranicznych i rozwój nowych rynków, tj. New Connect.

Można prognozować, że fundusze emerytalne przeznaczałyby rocznie na inwestycje na rynku wtórnym od 6168,25 mln zł. w 2011 roku do 10998,22 mln zł. w 2020 roku, a także partycypowałyby w rynku IPO, absorbując od 1542,06 mln. zł. w 2011 roku do 2750,56 mln. zł. w 2020 roku (przy założeniu dotychczasowego poziomu składki 7,3\% podstawy wymiaru na ubezpieczenie emerytalne). Jest to stały, regularny dopływ kapitału na rynek pierwotny, który w znacznej mierze stanowi o perspektywach jego rozwoju.

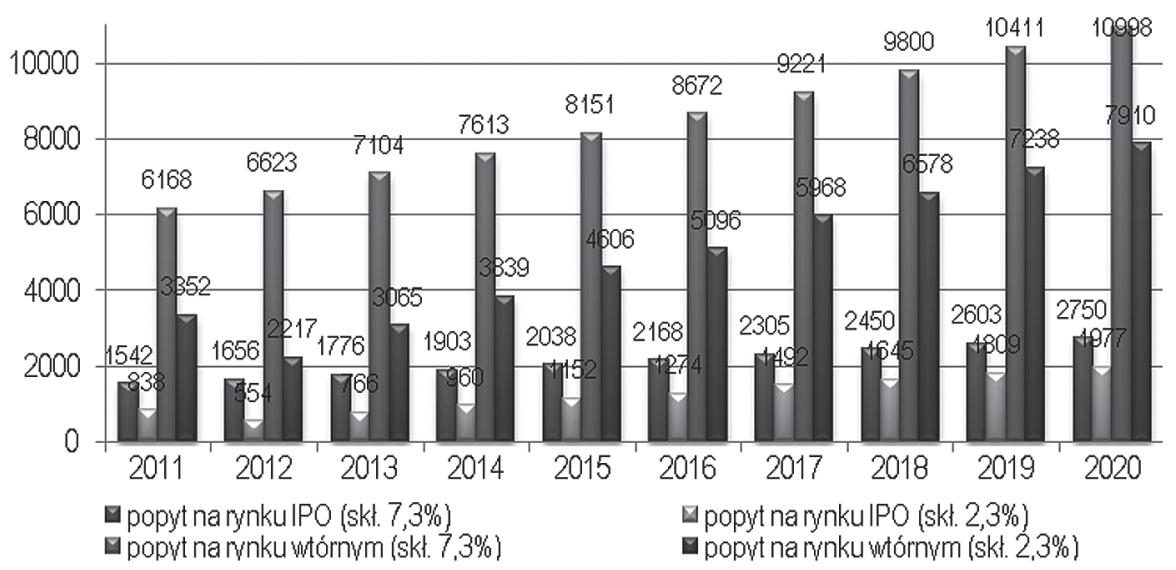

Wykres 4. Struktura popytu OFE na rynku giełdowym - prognoza na lata 2011-2020 Źródło: obliczenia własne na podstawie danych KNF i GPW S.A.

Zatem, w ślad za radykalnym obniżeniem składki przekazywanej do OFE, bardziej zasadne wydaje się ustalenie limitu zaangażowania w skarbowe instrumenty dłużne oraz zdecydowane zwiększenie limitu na inwestycje w akcje spółek notowanych na regulowanym rynku giełdowym poczynając od 2011 roku do 60-65\% aktywów. OFE, kumulujące środki o charakterze wielo- 
letnim, powinny generować wzrost wartości zarządzanych aktywów czerpiąc z potencjału rozwoju gospodarki. W tym celu w interesie zarówno członków funduszy, uczestników rynku kapitałowego jak i całej gospodarki, leży zabezpieczenie stałego dopływu kapitału na finansowanie publicznych emisji akcji na rynku giełdowym.

Biorąc pod uwagę specyfikę polityki inwestycyjnej, nawet przy znacznej liberalizacji limitu zaangażowania w akcje, trudno się spodziewać, że fundusze emerytalne będą całkowicie pomijać skarbowe instrumenty dłużne w alokacji portfela, gdyż jest to niezgodne $\mathrm{z}$ zasadami dywersyfikacji i stabilizacji portfela inwestycji. Obecnie fundusze emerytalne należą do najważniejszych inwestorów na rynku dłużnych papierów skarbowych. Ich udział w finansowaniu zadłużenia krajowego Skarbu Państwa wynosi ok. 25\% ${ }^{16}$.

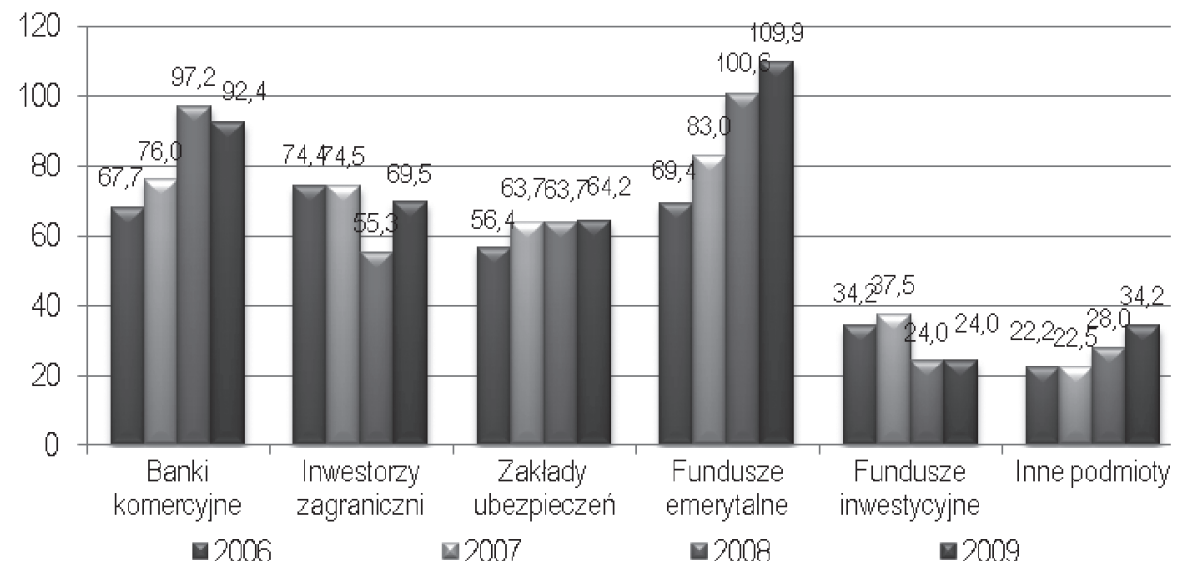

Wykres 5. Zaangażowanie najważniejszych grup inwestorów na rynku obligacji skarbowych w Polsce w latach 2006-2009 (w mld zł.)

Źródło: Rozwój systemu finansowego w Polsce w 2009 r., NBP, Warszawa 2010.

Mając na uwadze, że znaczne zwiększenie udziału akcji w portfelu OFE przyczyni się do wzrostu zmienności wartości portfela, należy spodziewać się, że OFE będą w celu ograniczania ryzyka włączać do portfela skarbowe instrumenty dłużne. Jeśli w sposób zasadniczy nie zostanie poszerzony wachlarz dostępnych dla OFE instrumentów finansowych oraz limitów na pozaskarbowe instrumenty dłużne znajdujące się w obrocie zorganizowanym, to biorąc pod uwagę dotychczasową praktykę oraz płytkość i ograniczoną

\footnotetext{
${ }^{16}$ Informacja o dziatalności inwestycyjnej funduszy emerytalnych w okresie 29.09.2006-30.09.2009, KNF, Warszawa 2009.
} 
ofertę polskiego rynku kapitałowego, a także rosnące potrzeby pożyczkowe państwa, będą one nadal znaczną część portfela inwestować w skarbowe instrumenty dłużne: od 40 do $60 \%$ portfela. Taka sytuacja jest bardzo prawdopodobna, bowiem na akcje limit ustalony jest na poziomie maksymalnego zaangażowania, a nie minimalnego obowiązkowego. Stąd fundusze emerytalne w sytuacji wzrostu stóp procentowych i niekorzystnej koniunktury na rynku giełdowym, będą w sposób naturalny zwiększały zaangażowanie w skarbowe papiery dłużne, bowiem rynek instrumentów pozaskarbowych jest w Polsce bardzo skromny.

\section{KONSEKWENCJE WPROWADZANYCH ZMIAN DLA INSTYTUCJI POŚREDNICTWA FINANSOWEGO}

Istotne znaczenie dla kondycji uczestników rynku kapitałowego może mieć również wprowadzenie dodatkowej możliwości dobrowolnego gromadzenia kapitału na cele emerytalne w ramach IKZE. Obecnie w ramach dobrowolnego zabezpieczenia emerytalnego funkcjonują już dwie formy oszczędzania indywidualne konta emerytalne (IKE) oraz pracownicze programy emerytalne (PPE). Jednakże, jak wykazują badania, żadna $\mathrm{z}$ tych form nie zyskała popularności głównie $\mathrm{z}$ powodu znikomej atrakcyjności stosowanych zachęt podatkowych (w postaci zwolnienia tylko z podatku od zysków kapitałowych) ${ }^{17}$. Natomiast, zarówno IKE, PPE oraz proponowane IKZE mają zwolnienie z podatku od zysków kapitałowych. Wprowadzenie nowego produktu IKZE, który daje prawo do skorzystania $\mathrm{z}$ dodatkowej ulgi podatkowej (odliczenie wpłat od podstawy opodatkowania), będzie powodować dalszą marginalizację istniejących już form oszczędzania na IKE i PPE, które nie mają tej ulgi. Dzięki uprzywilejowanej pozycji IKZE będzie charakteryzować się wyższą efektywnością dla oszczędzającego niż pozostałe produkty finansowe oferowane w trzecim filarze. Takie rozwiązania podatkowe w połączeniu $\mathrm{z}$ planowana możliwością transferu całości środków finansowych z IKE do IKZE w 2012 roku (co pozwala na skorzystanie $z$ tej dodatkowej ulgi) może spowodować znaczący drenaż kont IKE. Należy spodziewać się znaczącego przepływu kapitału nie tylko między wymienionymi formami oszczędzania, ale i pomiędzy instytucjami finansowymi je prowadzącymi. Można spodziewać się, że część środków zgromadzonych na IKE w innych instytucjach finansowych, tj. zakłady ubezpieczeń na życie (ok. 43\% udziału w rynku IKE w 2010 roku), to-

${ }_{17}$ Wg szacunków Polskiej Izby Pośredników Ubezpieczeniowych i Finansowych prawie 70\% rachunków IKE to tzw. „martwe konta”, na których nie ma regularnych wpłat. 
warzystwa funduszy inwestycyjnych (ok. 36\% udziału w rynku IKE w 2010 roku), podmioty prowadzące działalność maklerską (ok. 11\% udziału w rynku IKE w 2010 roku) oraz banki (ok. 10\% udziału w rynku IKE w 2010 roku), zostanie przeniesiona do powszechnych towarzystw emerytalnych, które również będą mogły oferować IKZE. Można przypuszczać, że takie rozwiązanie ma częściowo zrekompensować PTE utraconą na rzecz ZUS część przekazywanej składki na ubezpieczenie emerytalne. Dodatkowo, biorąc pod uwagę wyniki sondażu przeprowadzonego przez CBOS, w którym 23\% ankietowanych wskazuje lokatę bankową jako najbardziej opłacalny, dający szansę na najwyższe zyski, bezpieczny sposób lokowania oszczędności ${ }^{18}$, można spodziewać się przepływu części środków z depozytów (do wysokości limitu ulgi w podatku dochodowym) na IKZE prowadzone przez banki. $Z$ uwagi na długookresowy charakter inwestowanych środków w ramach IKZE, ta forma oszczędności emerytalnych może pozytywnie wpłynąć na stabilność systemu bankowego, co jest niewątpliwą zaletą zważywszy na perturbacje związane $\mathrm{z}$ obecnym kryzysem finansowym.

Warto wreszcie wspomnieć również o znaczących konsekwencjach proponowanych zmian w systemie emerytalnym na rynek samych powszechnych towarzystw emerytalnych zarządzających OFE. W momencie wdrażania reformy emerytalnej, w 1999 roku na rynku powstało 21 PTE, które zgodnie $\mathrm{z}$ założeniami utworzyły po jednym otwartym funduszu emerytalnym. W miarę rozwoju rynku, postępowała jego konsolidacja poprzez fuzje i przejęcia, w efekcie zaś na koniec 2010 roku na rynku funkcjonowało już tylko 14 PTE. Udział w rynku trzech największych ze względu na wartość aktywów funduszy emerytalnych (Aviva OFE, OFE PZU oraz ING OFE) wynosił 63\% w 2010 roku. Rynek funduszy emerytalnych ze względu na sztywność popytu oraz wysoką homogeniczność oferowanego produktu cechuje się ograniczoną konkurencją. Radykalne zmniejszenie tempa wzrostu aktywów OFE oraz ograniczenie możliwości akwizycji wyłącznie do rynku pierwotnego, w efekcie spowoduje obniżenie wyniku finansowego towarzystw emerytalnych. Jednocześnie proponowany projekt w zasadzie przekreśla szanse na rozwój produktu emerytalnego oferowanego przez OFE w kierunku różnicowania profilu ryzyko-dochód i wprowadzenia multifunduszowości. Bowiem, rolę funduszu bezpiecznego, dla osób w wieku przedemerytalnym przejmuje FUS. Wzrost ryzyka politycznego, duża zmienność regulacji prawnych w zakresie systemu emerytalnego oraz istotne obniżenie rentowności biznesu PTE, to wszystko prawdopodobnie będzie skutkować decyzją akcjonariuszy o wycofaniu się z tego typu działalności. Ponadto, ograniczenie możliwości akwiz-

${ }^{18}$ Polacy a fundusze inwestycyjne, CBOS, Warszawa 2009. 
ycji na rynku wtórnym, co prawda przyczyni się do redukcji kosztów OFE, ale $\mathrm{z}$ drugiej strony będzie czynnikiem konserwującym udziały w rynku poszczególnych funduszy. Zatem, można spodziewać się fuzji i przejęć na rynku PTE, co przyczyni się do znacznego osłabienia i zaniku konkurencji na rynku funduszy emerytalnych.

\section{ZAKOŃCZENIE}

Proponowane przez rząd zmiany regulacji prawnych w systemie emerytur kapitałowych, mające na celu przede wszystkim wdrożenie rozwiązań optymalnych z punktu widzenia systemu finansów publicznych, będzie miało niewątpliwie daleko idące konsekwencje dla rozwoju i funkcjonowania rynku finansowego w Polsce. Istotne skutki dla rozwoju rynku kapitałowego będzie miała zmiana dotycząca zmniejszenia składki przekazywanej do OFE z 7,3\% do 2,3\% podstawy wymiaru na ubezpieczenie emerytalne od maja 2011 roku, co będzie skutkowało zmniejszeniem dynamiki przyrostu wartości aktywów OFE oraz redukcją strumienia kapitału kierowanego na rynek kapitałowy. Jedynie szybka rewizja ograniczeń i limitów inwestycyjnych dla OFE, idąca w kierunku zdecydowanego zwiększenia możliwości inwestowania w instrumenty udziałowe oraz pozaskarbowe, pozwoli na ewentualne utrzymanie zaangażowania funduszy na rynku giełdowym.

Dodatkowo, planowana zmiana regulacji prawnych stawia pod znakiem zapytania możliwość utworzenia funduszy konserwatywnych oraz przyczyni się do powstawania przepływów kapitałowych między instytucjami finansowymi zarządzającymi oszczędnościami, których bodźcem jest wyłącznie mechanizm podatkowy, co nie stymuluje konkurencyjności i innowacyjności rynku finansowego. Sprzyja to raczej powstawaniu dodatkowych kosztów zarówno operacyjnych, jak i informacyjnych oraz zmniejszeniu transparentności mechanizmów lokowania oszczędności na cele emerytalne na rynku kapitałowym.

\section{BIBLIOGRAFIA}

Boni M., Uzasadnienie do Ustawy o zmianie niektórych ustaw zwiazanych z funkcjonowaniem systemu ubezpieczeń spotecznych, KPRM 2011, www.kprm.gov.pl.

Czerwińska T. T., Polityka inwestycyjna instytucji ubezpieczeniowych - istota, uwarunkowania, instrumenty, Wyd. Uniwersytetu Gdańskiego, Gdańsk 2009.

Informacja o dziatalności inwestycyjnej funduszy emerytalnych w okresie 29.09.2006 30.09.2009, KNF, Warszawa 2009. 
Informacja o dziatalności inwestycyjnej funduszy emerytalnych w okresie 28.09.2007 30.09.2010, KNF, Warszawa 2010.

Kołodziejczyk K., Systemy emerytalne w Ameryce Eacińskiej: od repartycji do kapitalizacji,

Wydawnictwo WSB w Poznaniu, Poznań 2004.

Polacy a fundusze inwestycyjne, CBOS, Warszawa 2009.

Rozporzadzenie Rady Ministrów z dnia 3 lutego 2004 r. w sprawie określenia maksymal-

nej częśi aktywów OFE, jaka może zostać ulokowana w poszczególnych kategoriach

lokat, oraz dodatkowych ograniczeń w zakresie prowadzenia dziatalności lokacyjnej przez fundusze emerytalne, Dz.U. Nr 32, poz. 276, z późn. zm.

Rozporzadzenie Ministra Finansów z 18 lutego 2000 r. w sprawie ogólnego zezwolenia na

lokowanie aktywów funduszy emerytalnych poza granicami kraju, Dz.U.00.15.182.

Rozwój systemu finansowego w Polsce w 2009 r., NBP, Warszawa 2010.

Ustawa z dnia 28 lipca 1997 r. o organizacji i funkcjonowaniu funduszy emerytalnych,

Dz. U. z 20 XI 1997 r. z późn. zm.

Ustawa z dnia 20 kwietnia 2004 r. o indywidualnych kontach emerytalnych.

Ustawa o zmianie niektórych ustaw zwiazanych z funkcjonowaniem systemu ubezpieczeńn spotecznych, projekt z dnia 3 marca 2011 r., www.kprm.gov.pl.

Uwagi IZFA do projektu ustawy o zmianie niektórych ustaw związanych z funkcjonowaniem systemu emerytalnego, Warszawa 2011.

\section{SKUTKI ZMIAN REGULACJI PRAWNYCH W ZAKRESIE EMERYTUR KAPITAŁOWYCH DLA ROZWOJU RYNKU FINANSOWEGO W POLSCE}

\section{STRESZCZENIE}

Funkcjonujące od 1999 roku otwarte fundusze emerytalne są pod względem wielkości aktywów znaczącą formacją finansową kształtującą potencjał systemu finansowego w Polsce. Doświadczenia wielu krajów pokazują, że aktywność inwestycyjna funduszy emerytalnych należy do tzw. akceleratorów rozwoju rynku finansowego zarówno $\mathrm{w}$ aspekcie organizacyjno-prawnym, jak również sama akumulacja długoterminowego kapitału w tych instytucjach przyczynia się do generowania popytu na profesjonalizację i specjalizację procesu inwestycyjnego oraz stymuluje innowacje finansowe ${ }^{19}$. Wartość zarządzanego przez fundusze emerytalne portfela inwestycji sprawia, że ich decyzje wywierają obecnie znaczny wpływ na funkcjonowanie polskiego rynku kapitałowego.

Celem opracowania jest identyfikacja i analiza przewidywanych skutków zmian regulacji prawnych w zakresie emerytur kapitałowych dla rozwoju rynku finansowego w Polsce. W publikacji zaprezentowano również wyniki prognozy zaangażowania ka-

${ }^{1}$ Por. K. Kołodziejczyk, Systemy emerytalne w Ameryce Eacińskiej: od repartycji do kapitalizacji, Wydawnictwo WSB w Poznaniu, Poznań 2004, s. 102-103. 
pitałowego otwartych funduszy emerytalnych na rynku giełdowym akcji, co pozwoli na ocenę implikacji proponowanych zmian dla rynku GPW w Warszawie.

\title{
THE EFFECTS OF CHANGES IN REGULATION OF FUNDED PENSIONS FOR FINANCIAL MARKET DEVELOPMENT IN POLAND
}

\author{
SUMMARY
}

The open pension funds, functioning from 1999, are under in terms of size the second active bodies (for banks) financial formation influencing the potential of the financial system in Poland. The experiences of many countries show that the investment activity of pension funds belong to the so-called accelerators of the development of the financial market. The value of the investment portfolio management by pension funds determines that their decisions have the considerable influence on functioning of the Polish capital market. The commitment of pension funds on the capital market can have a stabilization function on the economic situation on the market, which is essential for the stability of the financial system especially during the global economic crisis.

The aim of the paper is the identification and analysis of the foreseen results of the changes of legal controls in the range of capital pensions for the development of the financial market in Poland. 
